\title{
In vitro antimicrobial activity of plant active components against Pseudomonas lundensis and Listeria monocytogenes
}

\author{
KHABAT NOORI HUSSEIN ${ }^{1,2 *}$ @ , TÍMEA MOLNÁR ${ }^{3}$, RICHARD PINTER $^{1}$, \\ ADRIENN TOTH ${ }^{1}$, EMNA AYARI ${ }^{1}$, LASZLO FRIEDRICH ${ }^{1}$, \\ ISTVAN DALMADI $^{1}$ and GABRIELLA KISKÓ ${ }^{3}$
}

\footnotetext{
${ }^{1}$ Department of Refrigeration and Livestock Products Technology, Faculty of Food Science, Szent István University, Ménesi út 43-45, H-1118, Budapest, Hungary

${ }^{2}$ Department of Animal Production, College of Agriculture, University of Duhok, Zakho Street 38, 42001, Duhok, Kurdistan Region, Iraq

${ }^{3}$ Department of Microbiology and Biotechnology, Faculty of Food Science, Szent István University, Somlói út 14-16, H-1118, Budapest, Hungary
}

\section{CONFERENCE FULL PAPER}

Received: August 12, 2020 • Accepted: September 22, 2020

Published online: November 18, 2020

(C) 2020 The Author(s)

\begin{abstract}
This work aimed to study the antimicrobial activity of eight various components of plant origin on the growth of Pseudomonas lundensis and Listeria monocytogenes. Different in vitro methods were used: agar plate diffusion, micro atmosphere, agar hole diffusion, micro-dilution, and gradient-plate method. In the first agar plate assay, p-cymene and $\gamma$-terpinene did not inhibit the growth of the tested bacteria therefore they were not used in further experiments. Both $\alpha$-pinene and limonene were only partially effective, but these were screened only for their partial inhibition. The other four components completely inhibited the growth of the tested bacteria. Using the agar-well diffusion method showed that carvacrol and thymol were found to be the most effective active components, thymol had minimum inhibitory concentration (MIC) at $1.563 \mathrm{mg} / \mathrm{mL}$, however, in the case of carvacrol, MIC was $7.813 \mu \mathrm{L} / \mathrm{mL}$. Additionally, eugenol and camphor
\end{abstract}

* Corresponding author. Department of Refrigeration and Livestock Products Technology, Faculty of Food Science, Szent István University, Menesi ut 43-45, H-1118, Budapest, Hungary. E-mail: khabat.noori@uod.ac, khagri86@yahoo.com 
show the same results but in higher concentrations. Gradient plate method was used to determine MIC values, in which it has been proved that carvacrol and thymol possess strong antimicrobial activity, no growth of tested bacteria was observed with carvacrol $(100 \mu \mathrm{L} / \mathrm{mL})$, while thymol exhibited MIC of 1.887 $\mathrm{mg} / \mathrm{mL}$ against $P$. lundensis and $0.943 \mathrm{mg} / \mathrm{mL}$ needed to show complete inhibition of Listeria monocytogenes. Further experiments are needed to determine the optimum concentrations of the active components against $P$. lundensis and L. monocytogenes.

\section{KEYWORDS}

active compounds, antimicrobial activity, antibacterial assays, pathogenic bacteria

\section{INTRODUCTION}

Nowadays, despite the advanced hygiene regulations, stringent regulations, and precautions many foodborne infections and poisonings can pose a threat to human health. One reason for this is that pathogenic bacteria have protective mechanisms or resistance to old and new antibiotic formulations causing serious food-borne infections, which in many cases are fatal. According to statistics, more infectious diseases have occurred in recent years, and the number of pathogenic bacteria and fungi has increased. This is prevalent in developing countries, but according to a 2012 statement by the WHO (2012), it can be a problem for all humans worldwide. Pseudomonas lundensis, a gramnegative bacterium that is generally characterized by a cell wall consisting of a thin layer while Listeria monocytogenes, a gram-positive bacteria has thicker but simpler cell wall of peptidoglycan. They often cause deterioration the dairy products, fresh vegetables, meat, and fish (Yazdankhah et al., 2001). P. lundensis is among the most commonly detected Pseudomonas species that cause spoilage in chilled meat, milk, and milk products (Liu et al., 2015; Mallet et al., 2012). L. monocytogenes is an important causative agent of foodborne diseases that can be found in raw and processed foods that are contaminated during and/or after processing, it is frequently transferred through the consumption of contaminated food and beverages (Belák and Maráz, 2015). Although the Listeria genus comprises fifteen species, L. monocytogenes almost exclusively is the causative agent of human listeriosis. The number of foodborne cases caused by L. monocytogenes in 2012 in the European Union was 1,642 and 13 of them were recorded in Hungary (EFSA, 2014). Therefore, inhibition or elimination of these pathogenic bacteria is an essential task for microbiologists and food producers.

The use of various natural antimicrobial components of plant origin and combinations thereof against various pathogens may be a better solution to this problem compared to synthetic additives such as Butylated hydroxytoluene. These natural substances have long been used for a variety of therapeutic and religious purposes, but they are also well recognized in the food, cosmetic and medical applications. Numerous studies and experiments address their beneficial or antimicrobial, antiseptic, or antifungal properties. However, it has the disadvantage that when used in larger amounts, they can negatively affect the organoleptic properties of different foods, and change their taste, smell, and aroma. For these reasons, it would be important to determine the minimum concentration of various antimicrobial agents that are sufficiently effective against various pathogens but do not significantly alter the properties of the food (Burt, 2004; Hussein et al., 2019).

The active constituents of essential oils are mostly terpenes and terpenoids: monoterpenes or sesquiterpenes and may also be diterpenes and triterpenes. The monoterpenes can be classified 
<smiles>CC1=CC=C(C(C)C)CC1</smiles>

$\alpha$-terpinene<smiles>C=CCc1ccc(O)c(OC)c1</smiles>

Eugenol<smiles>C=C1CC2CCC1(C)C2(C)C</smiles><smiles>C=C(C)C1CC=C(C)CC1</smiles>

Camphor<smiles>Cc1ccc(C(C)C)cc1O</smiles>

Carvacrol
Limonene<smiles>Cc1ccc(C(C)C)c(O)c1</smiles>

Thymol

Fig. 1. Structure of selected active compounds (from Burt, 2004)

based on their diverse functional groups: terpinene, pinene; alcohols, e.g. geraniol; aldehydes, e.g. citral; ketones, e.g. camphor or phenols, e.g. thymol and carvacrol (Bakkali et al., 2008) (Fig. 1). Some of these active components such as carvacrol are capable of breaking down the lipopolysaccharide membrane of gram-negative bacteria, disrupting active cell transport, and may also cause coagulation. It can interact with the double lipid layer of the cytoplasmic membrane of planktonic cells, which inhibits proton permeability, leading to cellular leakage, which later results in cell death (Ilham et al., 2014; Luz et al., 2012). This study was conducted using different methods to illustrate the in vitro antimicrobial activity of different active components against food spoilage and food pathogenic bacteria P. lundensis and L. monocytogenes.

\section{MATERIALS AND METHODS}

\section{Material and strains}

In this experiment, P. lundensis CCP5 and L. monocytogenes ATCC 4699 were selected as targeted strains from the Department of Microbiology and Biotechnology, Faculty of Food Science at Szent István University. The antimicrobial components (carvacrol, thymol, eugenol, camphor, $\alpha$-pinene, limonene, p-cymene, and $\gamma$-terpinene) were obtained from SIGMA (Germany).

\section{Measurement procedure and experimental design}

For each of the assays, freshly inoculated cultures on Tryptone Glucose Extract (TGE) (Merck, Germany) agar were incubated for $24 \mathrm{~h}$. P. lundensis was incubated at $30{ }^{\circ} \mathrm{C}$ and $L$. monocytogenes was incubated at $37^{\circ} \mathrm{C}$. The culture suspension was adjusted to $10^{8}$ cells by 0.5 
optical density (OD) by using a densitometer (DEN-1B, McFarland), and the density of the diluted working culture was set to approximately $10^{6} \mathrm{CFU} \mathrm{mL} \mathrm{m}^{-1}$. Three replicates were performed of each component per microbe. In this study five different methods were applied including agar diffusion method, micro atmosphere method, agar-well diffusion method, microdilution method and gradient-plate method, in order to evaluate the in vitro antimicrobial activity of active components (carvacrol, thymol, eugenol, camphor, $\alpha$-pinene, limonene, p-cymene, and $\gamma$-terpinene) that are important in the food industry against P. lundensis and L. monocytogenes.

Agar diffusion method. The cell concentration of P. lundensis and L. monocytogenes was adjusted to $10^{8}$ cells $/ \mathrm{mL}$ by OD and diluted to $10^{6}$ cells $/ \mathrm{mL}$. Subsequently, the plate was cast with $1 \mathrm{~mL}$ of culture in petri dishes with $20 \mathrm{~mL}$ TGE agar, and a sterile disc-shaped filter paper was placed in the centre of the plate with a tweezer sterilized with flaming. For this small disk, 4 $\mu \mathrm{L}$ of the diluted active component was pipetted in a suitable ratio. In the case of a control, ethanol was the dissolving component pipetted into the disc. The stock suspension concentration was $200 \mathrm{mg}$ camphor $/ 200 \mu \mathrm{L}$ ethanol and for thymol $30 \mathrm{mg}$ thymol/600 $\mu \mathrm{L}$ ethanol. The petri dishes were packaged to prevent evaporation of volatile components and incubated upsidedown for 24 and $48 \mathrm{~h}$ at the appropriate temperatures. Zones of inhibition (mm) were measured using a digital Vernier caliper (Workzone-calliper) (Hussein et al., 2019).

Micro atmosphere method. Similar to the agar diffusion method, $10^{6}$ microbial suspensions were used. The filter paper discs were $2 \mathrm{~cm}$ in diameter and placed on top of the petri dishes upside-down. $30 \mu \mathrm{L}$ of the antimicrobial component was pipetted onto the filter papers. Ethanol was also used as a control. Inhibition zones around the disk were also measured with a digital caliper after incubation at 30 or $37^{\circ} \mathrm{C}$.

Agar-well diffusion method. In this method, the culture suspension of $10^{6} \mathrm{CFU}$ was pipetted into the petri dishes, then $\sim 20 \mathrm{~mL}$ TGE agar added and left to solidify. Using special cork metal sterilized hole of $8 \mathrm{~mm}$ in diameter was made in each petri dish and filled with $80 \mu \mathrm{L}$ of the appropriate dilution of the active components. Half-dilution of the liquid component was made from the undiluted component. For the non-liquid components, a stock solution of $30 \mathrm{mg}$ thymol/600 $\mu \mathrm{L}$ ethanol was prepared and diluted in half with distilled water. For the other component, a stock solution of $200 \mathrm{mg}$ camphor/200 $\mu \mathrm{L}$ ethanol was prepared and further diluted (in half) with distilled water. Ethanol and sterile distilled water were pipetted into the holes in the case of control. Inhibition zones around the holes were measured (Balouiri et al., 2016).

Micro-dilution method. Measurements were made on a 96 well-plate. The stock solution of carvacrol was made with $200 \mu \mathrm{L} / \mathrm{mL}$ ethanol and thymol $30 \mathrm{mg} / 600 \mu \mathrm{L}$ ethanol. Then $50 \mu \mathrm{L}$ of TGE was pipetted into each well. Into the first well of a 96 -well microtiter plate, $50 \mu \mathrm{L}$ of appropriately diluted active components was placed. Micro dilution and mixing was done via a pipette 2-3 times for homogenization, then $50 \mu \mathrm{L}$ was pipetted into the right well and serial 8fold dilutions were performed by transferring $50 \mu \mathrm{L}$ from well to well (on culumn). From the last well of the column $50 \mu \mathrm{L}$ was discarded. Then $50 \mu \mathrm{L}$ of the cell bacterial suspensions was pipetted into the appropriate well. Ethanol was also used as a control. After the incubation $10 \mu \mathrm{L}$ of resazurin aqueous solution was pipetted into each well. The final volume in each well remained $160 \mu \mathrm{L}$. The resazurin solution was used to determine the microbial growth, the 
pink color indicated the growth of microbes after a while, if the color remained blue that mean the growth was inhibited by active components (Semeniuc et al., 2017). Based on these, the minimum inhibitory concentration (MIC) value was determined. Resazurin solution was made by dissolving $0.025 \mathrm{~g}$ of resazurin in $1 \mathrm{~mL}$ of sterile distilled water. This was then added to a preweighed $8 \mathrm{~mL}$ TSB (Tryptic Soy Broth) in a sterile eppendorf tube. Meanwhile, $0.014 \mathrm{~g}$ of menadione was dissolved in $1 \mathrm{~mL}$ of DMSO and added to the previously made resazurin solutions.

Gradient-plate method. In this method, culture suspension of $10^{6} \mathrm{CFU}$ was pipetted into the petri dishes adding $15 \mathrm{~mL}$ TGE agar, then this suspension was added to TGE agar and mixed. In the first layer, $15 \mathrm{~mL}$ of TGE agar was added to the petri dishes and left to solidify at an angle of $45^{\circ} .15 \mathrm{~mL}$ of agar-antimicrobial mixture poured onto the first solid agar layer and allowed to solidify in the normal position. The wrapped dishes were placed in a refrigerator for $48 \mathrm{~h}$ and then 4 strips parallel to the agar surface were drawn on the agar surface with a sterile microfoam swab soaked in microbial suspension. The plates were incubated at 30 and $37^{\circ} \mathrm{C}$ for 24 and $48 \mathrm{~h}$, respectively, and the bacterial growth along the strips was measured with a ruler, then the MIC values were determined (Balouiri et al., 2016).

\section{RESULTS AND DISCUSSION}

\section{Agar diffusion}

Based on the 24-h results obtained (Table 1), it can be observed that $\gamma$-terpinene and p-cymene did not show antimicrobial activity against the studied bacteria. Additionally, P. lundensis was partially inhibited by $\alpha$-pinene and the similar status was noticed with limonene against Listeria monocytogene. On the other hand, carvacrol showed the highest activity against $P$. lundensis and L. monocytogenes followed by eugenol and thymol.

\section{Micro-atmospheric diffusion}

In this method, active components were not in direct contact with the inoculated medium, therefore using larger discs and higher amounts of the antimicrobial component were applied.

Table 1. Inhibition zones ( $\mathrm{mm} \pm$ standard deviation) of Pseudomonas lundensis CCP5 and Listeria monocytogenes ATCC after 24- and 48-h using agar diffusion method

\begin{tabular}{lccccc}
\hline & \multicolumn{2}{c}{$24 \mathrm{~h}$} & & \multicolumn{2}{c}{$48 \mathrm{~h}$} \\
\cline { 2 - 3 } \cline { 5 - 6 } Active components & P. lundensis & L. monocytogenes & & P. lundensis & L. monocytogenes \\
\hline Thymol & $10.287 \pm 0.459$ & $8.44 \pm 1.145$ & & $10.01 \pm 0.592$ & $8.953 \pm 0.457$ \\
Eugenol & $10.497 \pm 0.656$ & $10.32 \pm 1.531$ & & $9.247 \pm 0.487$ & $11.902 \pm 0.99$ \\
$\alpha$-pinene & $9.14 \pm 0.556$ & - & & $9.65 \pm 0.765$ & $7.453 \pm 1.13$ \\
$\gamma$-terpinen & - & - & - & - & - \\
P-cymene & - & - & - & - \\
Limonene & $17.382 \pm 4.936$ & - & & $17.533 \pm 4.053$ & $7.12 \pm 0.22$ \\
Carvacrol & $9.345 \pm 0.735$ & $8.47 \pm 0.556$ & & $7.59 \pm 0.444$ & $8.25 \pm 0.03$ \\
Camphor & & & & &
\end{tabular}


Table 2. Inhibition zones ( $\mathrm{mm} \pm$ standard deviation) of Pseudomonas lundensis CCP5 and Listeria monocytogenes ATCC after 24 and $48 \mathrm{~h}$ using the micro-atmosphere diffusion method

\begin{tabular}{lccccc}
\hline & \multicolumn{2}{c}{$24 \mathrm{~h}$} & & \multicolumn{2}{c}{$48 \mathrm{~h}$} \\
\cline { 2 - 3 } \cline { 6 - 6 } Active components & P. lundensis & L. monocytogenes & & P. lundensis & L. monocytogenes \\
\hline Thymol & $23.725 \pm 3.479$ & - & & $23.567 \pm 1.087$ & $23.46 \pm 0.05$ \\
Eugenol & $20.16 \pm 3.33$ & - & - & $23.95 \pm 0.02$ & $25.46 \pm 0.165$ \\
$\alpha$-pinene & $23.795 \pm 1.336$ & - & & $23.527 \pm 0.912$ & $24.82 \pm 0.7709$ \\
Limonene & $20.424 \pm 0.772$ & - & & $22.57 \pm 0.7907$ & $22.77 \pm 0.238$ \\
Carvacrol & - & - & & $24.60 \pm 0.06$ & $22.84 \pm 0.00$ \\
Camphor & & & - & &
\end{tabular}

In this method only the five antimicrobial components (thymol, eugenol, $\alpha$-pinene, limonene, carvacrol, and camphor) were used that were active against the microbes in the previous experiment pipetted. Table 2 shows that $P$. lundensis was inhibited by thymol, eugenol, limonene, and carvacrol, but none of the components inhibited L. monocytogenes. This may be due to the fact that 24-h incubation was not sufficient for proliferation, so the zone of inhibition was not visible. Thymol, eugenol, carvacrol, and camphor also showed considerable activity against both bacteria, while $\alpha$-pinene and limonene showed only partial inhibition. Eugenol and camphor gave the highest inhibition zones.

\section{Agar-well diffusion}

Using agar-well diffusion method the active components diffuse from the holes into the agar, where they exhibit the antimicrobial activity against microbes. Based on the results of previous experiments, four antimicrobial components were applied: eugenol, carvacrol, camphor, and thymol. The results are summarized in Table 3. The MIC of eugenol was noticed at $62.5 \mu \mathrm{L} /$ $\mathrm{mL}$ for $P$. lundensis, and $15.3 \mu \mathrm{L} / \mathrm{mL}$ MIC was observed in the case of carvacrol. The first dilution of camphor had complete inhibition corresponding to a concentration of $500 \mathrm{mg} / \mathrm{mL}$. For thymol, the MIC value was $1.563 \mathrm{mg} / \mathrm{mL}$. In summary, the lowest MIC values for $P$. lundensis were observed for carvacrol and thymol after both 24 and $48 \mathrm{~h}$ incubation. In the case of L. monocytogenes after 24 and $48 \mathrm{~h}$ of incubation (Table 3), eugenol completely inhibited its growth up to the third limb, which was $31.25 \mu \mathrm{L} / \mathrm{mL} \mathrm{MIC}$, and MIC was 7.813 $\mu \mathrm{L} / \mathrm{mL}$ in the case of carvacrol. Thymol had MIC at $1.563 \mathrm{mg} / \mathrm{mL}$. After $48 \mathrm{~h}$ the MIC value of camphor remained at $500 \mathrm{mg} / \mathrm{mL}$. However, in the case of carvacrol, after another $24 \mathrm{~h} \mathrm{in-}$ cubation MIC was $3.9 \mu \mathrm{L} / \mathrm{mL}$. In conclusion, thymol and carvacrol were the most active components against L. monocytogenes. This result was in accordance with the result obtained by Gutierrez et al. (2009).

\section{Micro-dilution method}

In this method, the experiment was performed with both bacteria repeatedly to determine the MIC value of thymol and carvacrol. None of the experiments yielded appreciable results, nor did the control group (ethanol) show any growth. Therefore, another gradient plate method was used to determine MIC values. 
Table 3. Inhibition zones ( $\mathrm{mm} \pm$ standard deviation) of active components against Pseudomonas lundensis CCP5 and Listeria monocytogenes ATCC after 24- and 48-h using agar-well diffusion method

\begin{tabular}{|c|c|c|c|c|c|c|c|c|c|c|c|c|c|c|c|c|}
\hline \multirow{3}{*}{$\begin{array}{l}\text { Concentration } \\
{[\mu \mathrm{L} / \mathrm{mL}]}\end{array}$} & \multicolumn{8}{|c|}{ P. lundensis } & \multicolumn{8}{|c|}{ L. monocytogenes } \\
\hline & \multicolumn{2}{|c|}{ Eugenol } & \multicolumn{2}{|c|}{ Carvacrol } & \multicolumn{2}{|c|}{ Camphor } & \multicolumn{2}{|c|}{ Thymol } & \multicolumn{2}{|c|}{ Eugenol } & \multicolumn{2}{|c|}{ Carvacrol } & \multicolumn{2}{|c|}{ Camphor } & \multicolumn{2}{|c|}{ Thymol } \\
\hline & $24 \mathrm{~h}$ & $48 \mathrm{~h}$ & $24 \mathrm{~h}$ & $48 \mathrm{~h}$ & $24 \mathrm{~h}$ & $48 \mathrm{~h}$ & $24 \mathrm{~h}$ & $48 \mathrm{~h}$ & $24 \mathrm{~h}$ & $48 \mathrm{~h}$ & $24 \mathrm{~h}$ & $48 \mathrm{~h}$ & $24 \mathrm{~h}$ & $48 \mathrm{~h}$ & $24 \mathrm{~h}$ & $48 \mathrm{~h}$ \\
\hline 500 & $\mathrm{NA}$ & NA & NA & NA & $\begin{array}{c}8.54 \pm \\
0.38\end{array}$ & $\begin{array}{c}8.81 \pm \\
1.71\end{array}$ & NA & $\mathrm{NA}$ & NA & NA & $\mathrm{NA}$ & $\mathrm{NA}$ & $\begin{array}{c}10.885 \pm \\
1.237\end{array}$ & $\begin{array}{c}10.90 \pm \\
1.21\end{array}$ & NA & NA \\
\hline 250 & $\begin{array}{c}12.78 \pm \\
0.38\end{array}$ & $\begin{array}{c}11.87 \pm \\
0.17\end{array}$ & $\begin{array}{c}23.77 \pm \\
0.36\end{array}$ & $\begin{array}{c}20.41 \pm \\
0.65\end{array}$ & - & - & NA & $\mathrm{NA}$ & $\begin{array}{c}22.75 \pm \\
0.71\end{array}$ & $\begin{array}{c}22.3 \pm \\
2.40\end{array}$ & $\begin{array}{c}19.85 \pm \\
0.98\end{array}$ & $\begin{array}{c}19.5 \pm \\
0.63\end{array}$ & $\begin{array}{c}8.26 \pm \\
0.33\end{array}$ & $\begin{array}{c}8.26 \pm \\
0.33\end{array}$ & NA & NA \\
\hline 125 & $\begin{array}{c}12.00 \pm \\
1.053\end{array}$ & $\begin{array}{c}11.99 \pm \\
1.32\end{array}$ & $\begin{array}{c}21.45 \pm \\
1.69\end{array}$ & $\begin{array}{c}18.17 \pm \\
0.672\end{array}$ & - & - & NA & $\mathrm{NA}$ & $\begin{array}{c}19.19 \pm \\
1.15\end{array}$ & $\begin{array}{c}19.26 \pm \\
0.33\end{array}$ & $\begin{array}{c}17.56 \pm \\
0.44\end{array}$ & $\begin{array}{c}17.35 \pm \\
0.42\end{array}$ & - & - & NA & NA \\
\hline 62.5 & $\begin{array}{c}8.19 \pm \\
0.83\end{array}$ & $\begin{array}{c}9.25 \pm \\
0.53\end{array}$ & $\begin{array}{c}15.86 \pm \\
0.26\end{array}$ & $\begin{array}{c}15.15 \pm \\
0.56\end{array}$ & - & - & NA & NA & $\begin{array}{c}16.76 \pm \\
1.74\end{array}$ & $\begin{array}{c}18.17 \pm \\
0.95\end{array}$ & $\begin{array}{c}15.81 \pm \\
0.06\end{array}$ & $\begin{array}{c}15.55 \pm \\
0.14\end{array}$ & & & $\mathrm{NA}$ & NA \\
\hline 31.25 & - & - & $\begin{array}{c}12.78 \pm \\
0.40\end{array}$ & $\begin{array}{c}13.96 \pm \\
0.12\end{array}$ & - & - & NA & NA & $\begin{array}{c}10.54 \pm \\
0.05\end{array}$ & $\begin{array}{c}10.37 \pm \\
0.88\end{array}$ & $\begin{array}{c}14.20 \pm \\
1.06\end{array}$ & $\begin{array}{c}14.00 \pm \\
1.05\end{array}$ & & & NA & NA \\
\hline 15.63 & - & - & $\begin{array}{c}12.41 \pm \\
0.74\end{array}$ & $\begin{array}{c}12.77 \pm \\
0.49\end{array}$ & - & - & NA & NA & - & - & $\begin{array}{c}11.80 \pm \\
2.33\end{array}$ & $\begin{array}{c}11.57 \pm \\
2.09\end{array}$ & & & NA & NA \\
\hline 7.813 & - & - & - & $\begin{array}{c}10.15 \pm \\
0.14\end{array}$ & - & - & NA & NA & & & $\begin{array}{c}8.9 \pm \\
0.91\end{array}$ & $\begin{array}{c}8.07 \pm \\
0.07\end{array}$ & & & NA & NA \\
\hline 3.9 & & & & - & & & NA & $\mathrm{NA}$ & & & - & $\begin{array}{c}7.75 \pm \\
0.00\end{array}$ & & & NA & NA \\
\hline 25 & & & & & & & $\begin{array}{c}13.55 \pm \\
1.414\end{array}$ & $\begin{array}{c}14.08 \pm \\
1.38\end{array}$ & & & & - & & & $\begin{array}{c}16.54 \pm \\
0.48\end{array}$ & $\begin{array}{c}16.3 \pm \\
0.35\end{array}$ \\
\hline 12.5 & & & & & & & $\begin{array}{c}12.61 \pm \\
0.89\end{array}$ & $\begin{array}{c}13.22 \pm \\
0.38\end{array}$ & & & & & & & $\begin{array}{c}15.07 \pm \\
0.81\end{array}$ & $\begin{array}{c}14.95 \pm \\
0.70\end{array}$ \\
\hline 6.25 & & & & & & & $\begin{array}{c}10.6 \pm \\
0.21\end{array}$ & $\begin{array}{c}11.77 \pm \\
1.02\end{array}$ & & & & & & & $\begin{array}{c}12.96 \pm \\
0.11\end{array}$ & $\begin{array}{r}12.80 \pm \\
0.21\end{array}$ \\
\hline 3.125 & & & & & & & $\begin{array}{c}9.42 \pm \\
0.6\end{array}$ & $\begin{array}{c}11.31 \pm \\
1.07\end{array}$ & & & & & & & $\begin{array}{c}12.25 \pm \\
0.424\end{array}$ & $\begin{array}{r}11.92 \pm \\
0.60\end{array}$ \\
\hline 1.563 & & & & & & & $\begin{array}{c}8.93 \pm \\
0.78\end{array}$ & $\begin{array}{c}9.71 \pm \\
0.98\end{array}$ & & & & & & & $\begin{array}{l}8.39 \pm \\
0.43\end{array}$ & $\begin{array}{c}8.15 \pm \\
0.09\end{array}$ \\
\hline
\end{tabular}

NA: not available. 
Table 4. Inhibition zones ( $\mathrm{mm} \pm$ standard deviation) measured at different MIC for both Pseudomonas lundensis CCP5 and Listeria monocytogenes ATCC after 24 and $48 \mathrm{~h}$ using gradient plate method

\begin{tabular}{|c|c|c|c|c|c|}
\hline \multirow[b]{2}{*}{ Dilution ratio } & \multirow[b]{2}{*}{ Concentration } & \multicolumn{2}{|c|}{ P. lundensis } & \multicolumn{2}{|c|}{$\begin{array}{c}L . \\
\text { monocytogenes }\end{array}$} \\
\hline & & $24 \mathrm{~h}$ & $48 \mathrm{~h}$ & $24 \mathrm{~h}$ & $48 \mathrm{~h}$ \\
\hline Thymol 1. & $0.943 \mathrm{mg} / \mathrm{mL}$ & $26.67 \pm 4.726$ & $33.333 \pm 3.215$ & - & - \\
\hline Thymol 2. & $1.887 \mathrm{mg} / \mathrm{mL}$ & $8 \pm 3.605$ & $15.333 \pm 2.516$ & - & - \\
\hline Thymol 3. & $2.830 \mathrm{mg} / \mathrm{mL}$ & - & - & - & - \\
\hline Carvacrol 1. & $100 \mu \mathrm{L} / \mathrm{mL}$ & - & - & - & - \\
\hline Carvacrol 2. & $200 \mu \mathrm{L} / \mathrm{mL}$ & - & - & - & - \\
\hline Carvacrol 3. & $300 \mu \mathrm{L} / \mathrm{mL}$ & - & - & - & - \\
\hline
\end{tabular}

\section{Gradient plate method}

In this method, thymol and carvacrol were used as the two most active components from the previous methods applied in the current study. These were studied by the gradient plate method, whereby the antimicrobial material in the upper agar layer diffused into the lower TGE agar layer containing only agar. The components were used in three different concentrations to determine the MIC value. Table 4 shows that there was no growth of $L$. monocytogenes, which may indicate that the thymol and carvacrol were active to control the growth of this bacteria at the lowest MIC that was applied in this study, such antimicrobial activity was also confirmed by Lambert et al. (2001). For P. lundensis the growth was not noticed in the case of carvacrol. Thymol, on the other hand, at MIC values of $1.887 \mathrm{mg} / \mathrm{mL}$ inhibited the growth of $P$. lundensis during 24- and 48-h incubation. Comparing to the agar-hole diffusion experiment the MIC of thymol was 1,563 mg/ $\mathrm{mL}$ but using the gradient plate method MIC of $1.887 \mathrm{mg} / \mathrm{mL}$ inhibited the growth of $P$. lundensis.

\section{CONCLUSION}

Current findings indicate both thymol and carvacrol proved as the most active components against the studied bacteria. Additionally, this result indicates that $P$. lundensis has greater sensitivity than L. monocytogenes to the selected active components by applying micro-atmosphere diffusion and gradient plate method, while in agar-well diffusion method more sensitive to the active components was noticed with L. monocytogenes. This could be due to the thinner peptidoglycan cell wall, whereas L. monocytogenes has a simpler but thicker cell wall with a larger peptidoglycan layer making it more resistant to external influences and antimicrobial components. Further studies are required to determine the concentration of the combined amicrobial activity of active components.

\section{ACKNOWLEDGMENT}

The Project is supported by the European Union and co-financed by the European Social Fund (grant agreement no. EFOP-3.6.3-VEKOP-16-2017-00005). The authors would like to thank the 
laboratory technicians at the Department of Microbiology and Biotechnology, Faculty of Food Science for their help in conducting this research.

\section{REFERENCES}

Bakkali, F., Averbeck, S., Averbeck, D., and Idaomar, M. (2008). Biological effects of essential oils. Food and Chemical Toxicology, 4: 446-475.

Balouiri, M, Sadiki M., and Ibnsouda S.K. (2016). Methods for in vitro evaluating antimicrobial activity: A review, Journal of Pharmaceutical Analysis, 6(2): 71-79.

Belák, Á. and Maráz, A. (2015). Antagonistic effect of Pseudomonas sp. CMI-1 on foodborne pathogenic Listeria monocytogenes. Food Technology and Biotechnology, 53(2): 223-230.

Burt, S. (2004). Essential oils: their antibacterial properties and potential applications in foods. International Journal of Food Microbiology, 94: 223-253. https://doi.org/10.1016/j.ijfoodmicro.2004.03.022.

EFSA-European Food Safety Authority. (2014). Analysis of the baseline survey on the prevalence of Listeria monocytogenes in certain ready-to-eat (RTE) foods in the EU, 2010-2011 Part A: Listeria monocytogenes prevalence estimates. EFSA Journal, 12: 3547, https://doi.org/10.2903/j.efsa.2013.3241.

Gutierrez, L., Escudero A., Batlle R., and Nerın, C. (2009). Effect of mixed antimicrobial agents and flavors in active packaging films. Journal of Agricultural and Food Chemistry, 57: 8564-8571.

Hussein, K.N., Friedrich, L., Kisko, G., Ayari, E., Nemeth, C., and Dalmadi, I. (2019). Use of allyl-isothiocyanate and carvacrol to preserve fresh chicken meat during chilling storage. Czech Journal of Food Sciences, 37: 417-424. https://doi.org/10.17221/80/2019-CJFS.

Ilham, A.B., Aumaima, T.A., and Hamid, N.O. (2014). Antibacterial activity of carvacrol against different types of bacteria. Journal of Natural Sciences Research, 4(9).

Lambert, R.J.W., Skandamis, P.N., Coote, P.J., and Nychas, G.J.E. (2001). A study of the minimum inhibitory concentration and mode of action of oregano essential oil, thymol, and carvacrol. Journal of Applied Microbiology, 91: 453-462.

Liu, Y.J., Xie, J., Zhao, L.J, Qian, Y.F, Zhao, Y., and Liu, X. (2015). Biofilm Formation Characteristics of Pseudomonas lundensis Isolated from Meat. Journal of Food Science, 80(12): M2904-M2910, https://doi. org/10.1111/1750-3841.13142.

Luz, I.S., Gomes Neto, N.J., Tavares, A.G., Magnani, M., and Souza, E.L. (2012). Exposure of Listeria monocytogenes to sublethal amounts of Origanum vulgare $\mathrm{L}$ essential oil or carvacrol in a food-based medium does not induce direct or cross-protection. Food Research International, 48: 667-672.

Mallet, A., Guéguen, M., Kauffmann, F., Chesneau, C., Sesboué, A., and Desmasures, N. (2012). Quantitative and qualitative microbial analysis of raw milk reveals substantial diversity influenced by herd management practices. International Dairy Journal, 27: 13-21. https://doi.org/10.1016/j.idairyj. 2012.07.009.

Semeniuc, C.A., Pop, C.R., and Rotar, A.M. (2017). Antibacterial activity and interactions of plant essential oil combinations against Gram-positive and Gram-negative bacteria. Journal of Food and Drug Analysis, 25(2): 403-408. https://doi.org/10.1016/j.jfda.2016.06.002.

WHO. (2012). Publications of the World Health Organization are available on the WHO on: http://apps. who.int/medicinedocs/documents/s19125en/s19125en.pdf, 20 Avenue Appia, 1211 Geneva 27, Switzerland. 
Yazdankhah, S.P., Sørum, H., Larsen, H.J., and Gogstad, G. (2001). Rapid method for detection of grampositive and -negative bacteria in milk from cows with moderate or severe clinical mastitis. Journal of Clinical Microbiology, 39(9): 3228-3233.

Open Access. This is an open-access article distributed under the terms of the Creative Commons Attribution 4.0 International License (https://creativecommons.org/licenses/by/4.0/), which permits unrestricted use, distribution, and reproduction in any medium, provided the original author and source are credited, a link to the CC License is provided, and changes - if any - are indicated. (SID_1) 